\title{
SUSTAINABILITY VS. CORPORATE PURPOSE: WILL TRANSFORMING VALUES SHIFT THE PARADIGM?
}

\author{
Anne-Marie Weber-Elżanowska *
}

\begin{abstract}
The recently reignited debate on the corporate purpose focuses primarily on the question, whether sustainability-influenced stakeholderism may substitute the dominating shareholder value doctrine. Its outcomes remain vague. In order to add some extra fuel to the ongoing discussion, this examines an alternative research angle in order to investigate the impact of the sustainability postulate on the notion of the corporate purpose. According to the paper's core claim, profoundly changing values within society may propel a paradigm shift which would lead to the abandonment to the prevailing shareholder primacy doctrine. The paper establishes a theoretical framework build upon the concept of safety valves embedded in private law systems which open the legal system to judgements on morality (bonos mores) and enable its running "update" according to values cultivated by society at a given time. It also discusses preliminary empirical evidence which indicates that in light of the ongoing value transformation within society, safety valves in private law could enable the sustainability objective to invade the corporation "from the outside" and necessitate the reconceptualization of the corporate purpose. Consequently, even if the shareholder value model's triumph in the current corporate law debate is assumed, the process of delineating the corporate purpose and implementing it into corporate conduct is fenced-in by safety valves as institutions of general private law. As a result, the paper wishes to provoke the contemplation on whether it is actually up to the corporate law centered debate to decide, how the corporate purpose should be defined. It urges to consider the possibility, which the notion of the corporate purpose as perceived by society at large is already being subject to a profound value transformation towards sustainability and the corporate law debate is not to be considered as a driver of this process. This realization could bring about a denouement of the Gordian knot of the
\end{abstract}

Anne-Marie Weber-Elżanowska, University of Warsaw, Faculty of Law and Administration, Warsaw, Poland; a.weber@wpia.uw.edu.pl 
stakeholder $v$. shareholder primacy dispute and refocus the academic corporate law discussion on issues of legal design which would translate the "externally" reconceptualized corporate purpose into corporate law.

KEYWORDS: sustainability, corporate purpose, stakeholderism, social values, social norms, shareholder value, shareholder primacy, stakeholder, private law, safety valve, bonos mores

\section{INTRODUCTION}

The signs of a deteriorating climate, loss of biodiversity and aggravating social inequalities are the "grand challenge" of our times. ${ }^{2}$ The question, whether global economic development may still meet the needs of the present generation without compromising the ability of future generations to meet their own needs, ${ }^{3}$ sadly yields unequivocal answers. It seems that the global community currently navigates an unsustainable route of development.

The problem of (un)sustainable development has recently pushed the corporate law academic community into a heated debate about the notion of the corporate purpose. ${ }^{4}$ This must seem very natural. Since a sustainable reorientation

1 Sjafjell, B.: Responding to the Grand Challenge of Our Time, in: Eftest $\varnothing 1$-Wilhelmsson, E., Sankari, S., Bask A. (eds.): Sustainable and Efficient Transport. Incentives for Promoting a Green Transport Market, Edward Elgar, 2019.

2 For a comprehensive overview of sustainable development goals according to the UN Agenda 2030 see: Sustainable Development Goals Report 2020, [https://unstats.un.org/sdgs/ report/2020/], accessed on 2.12.2020. As regards environmental policy challenges in the European context see: Report of the European Environment Agency, „The European environment - state and outlook 2020. Knowledge for transition to a sustainable Europe", [https:// www.eea.europa.eu/publications/soer-2020], accessed on 2.12.2020. On policy challenges see: Mauerhofer, V.: Sustainable Development Law in (Only) One World: Challenges and Perspectives for Governance and Governments, in: Mauerhofer, V., Rupo D., Tarquinio L. (eds.): Sustainability and Law. General and Specific Aspects, Springer 2020, p. 15-32.

3 The question is derived from the definition of sustainability as presented in the Brundtland Report „Our Common Future” from 1987, [http://www.un-documents.net/our-common-future. pdf], accessed on 2.12.2020.

4 See in particular: Research conducted within the program "The future of the corporation" led by Colin Mayer and within the British Academy, [https://www.thebritishacademy.ac.uk/ programmes/future-of-the-corporation/research/], accessed on 2.12.2020; Mayer, C.: Prosperity: Better business makes the greater good, Oxford University Press, 2018; contributions in: Sjåfjell, B., Bruner, C. (eds.): The Cambridge Handbook of Corporate Law, Corporate Governance and Sustainability, Cambridge University Press, 2020; Choudhury, B., Petrin, M.: Corporate Duties to the Public, Oxford University Press, 2019; Bebchuk, L., Tallarita, R.: The Illusory Promise of Stakeholder Governance, Working Draft, [https://papers.ssrn.com/ sol3/papers.cfm?abstract_id=3544978], accessed on 2.12.2020; Mayer C., Shareholderism ver - 
of economic development boils down to the need to change economic behavior in order to mitigate its harmful outcomes, corporations as crucial economic actors should be in the center of attention. Simply put: the understanding of the corporate purpose is fundamental in guiding directors how to manage the corporation which in turn shapes corporate conduct (economic behavior). Therefore, solving the corporate purpose riddle is of paramount importance and decisive for achieving sustainability objectives. ${ }^{5}$

The notion of the corporate purpose has been a recurring subject of discussion, most prominently mirrored in the Berle - Dodd deliberations. ${ }^{6}$ This dispute and the ensuing scholarly contributions produced a large body of research on the so-called stakeholder v. shareholder primacy dilemma, which basically revolves around the question whose interests (shareholders' alone or stakeholders' too) should define the content of the corporate purpose. Currently, there is an important new piece to be considered: Whereas a couple of decades ago the question of whom the corporation should serve was in fact a matter

sus Stakeholderism - A Misconceived Contradiction. A Comment on "The Illusory Promise of Stakeholder Governance" by Lucian Bebchuk and Roberto Tallarita, ECGI Law Working Paper No. 522/2020; Fisch, J., Solomon, S.: Should Corporations have a Purpose?, Law Working Paper No. 510/2020; Fleischer, H.: Unternehmensinteresse und intérêt social: Schlüsselfiguren aktienrechtlichen Denkens in Deutschland und Frankreich, ZGR 2018, p. 703-734; Lafarre, A., Van der Elst, C.: Shareholder Sustainabilty Activism in the Netherlands, ECGI Law Working Paper No. 396/2018; Bebchuk, L., Kastiel, K., Tallarita, R., For whom corporate leaders bargain, Working Draft, [https://papers.ssrn.com/sol3/papers.cfm?abstract_id=3677155], accessed on 2.12.2020; Gelter, M.: Taming or Protecting the Modern Corporation? Shareholder-Stakeholder debates in a comparative light, NYU Journal of Law and Business 7(2), 2011, p. 642-730; Cognac, P-H.: The reform of articles 1833 on social interest and 1835 on the purpose of the company if the French Civil Code: Recognition or Revolution, in: Festschrift für Karsten Schmidt zum 80. Geburtstag, C.H. Beck, 2019, p. 213-221; Licht A.: Varieties of Shareholderism: Three Views of the Corporate Purpose Cathedral, ECGI Law Working Paper No. 547/2020; Rock, E.: For Whom is the Corporation Managed in 2020? The Debate Over Corporate Purpose, ECGI Law Working Paper No. 515/2020; Hart, O., Zingales, L., Companies Should Maximize Shareholder Welfare Not Market Value, ECGI Finance Working Paper No. 521/2017.

5 Sjåfjell, B., Bruner, C.: Corporations and Sustainability, in: Sjåfjell, B., Bruner, C. (eds.): The Cambridge Handbook of Corporate Law, Corporate Governance and Sustainability, Cambridge University Press, 2020, p. 6.

6 Berle, A.: Corporate Powers as Powers of Trust, Harvard Law Review 44, 1931, p. 1049; Dodd, E. M.: For Whom are corporate managers trustees?, Harvard Law Review 45, 1932, p. 1145; Berle, A.: For Whom are corporate managers trustees: A note, Harvard Law Review 45, 1932, , p. 1365; For a comprehensive overview see: Sneirson, J.: The history of shareholder primacy, from Adam Smith through the rise of financialism, in: Sjåfjell, B., Bruner, C., (eds.): The Cambridge Handbook of Corporate Law, Corporate Governance and Sustainability, Cambridge University Press, 2020, p. 73-85 and Hill, J.: Then and Now: Professor Berle and the Unpredictable Shareholder, University Law Review, 33 2010, p. 1005, 1009-10. 
of political and ideological alternative choices, today it must be addressed in the context of planetary boundaries and the aforementioned (un) sustainable path of development. ${ }^{7}$ The capability of regeneration and renewal of natural capital is endangered. ${ }^{8}$ This completely new factual context must redefine today's debate and free it from the stigma of a perpetual and fruitless academic Gedankenexperiment. It seems necessary and prudent to evaluate past theoretical models against their real-world results and reassess the notion of the corporate purpose from such a perspective. It would be naïve to assume or advocate the immunity of corporate law concepts from transformative changes of our surroundings. The artificial social decontextualization of the company is a misconception. ${ }^{9}$ The "corporate world" is not detachable from the "outside world" and "corporations, like humans need to adapt to their environment and social context". 10

It is puzzling that while in line with a general growing awareness about sustainability problems in our society, ${ }^{11}$ expectations about sustainable behavior of individual economic actors (humans) are easily formulated and generally accepted, the same does not hold for corporate economic actors. The current corporate law debate seems stuck: Though complex solutions aiming at a redefinition of the corporate purpose and the facilitation of sustainable business conduct are being presented and debated by leading academics, ${ }^{12}$ the notion

7 Sjåfjell, B., Bruner, C.: Corporations and Sustainability, in: Sjåfjell, B., Bruner, C. (eds.): The Cambridge Handbook of Corporate Law, Corporate Governance and Sustainability, Cambridge University Press, 2020, p. 7-10.

8 On the notion of natural capital see: Mayer C.: Valuing the invaluable: how much is the planet worth?, Oxford Review of Economic Policy, 35(1) 2019, p. 109-119.

9 For an assessment of the need to include social context in EU company law policy making see: Horak, H., Poljanec, K.: Recent developments in European Company Law: A way forward to a more social Europe?, Intereulaweast, 5(2) 2018, p. 151-163.

10 Mayer, C.: Prosperity: Better business makes the greater good, Oxford University Press, 2018, p. 15.

11 See empirical data in sec. 3.2. below.

12 Mayer, C.: Prosperity: Better business makes the greater good, Oxford University Press, 2018; Choudhury, B., Petrin, M.: Corporate Duties to the Public, Oxford University Press, 2019; Johnston A.: Reforming English Company Law to Promote Sustainable Companies, European Company Law 11(2) 2014, p. 63-66; Mayer,, C.: The Future of the Corporation and the Economics of Purpose, ECGI Finance Working Paper No. 710/2020; Sjåfjell, B., Mähönen, J.: Upgrading the Nordic Corporate Governance Model for Sustainable Companies, European Company Law, 11(2) 2014, p. 58-62; Hsieh, N., Meyer, M., Rodin, D. van 't Klooster, J.: The social purpose of corporations, Journal of the British Academy, 6(s1) 2018, p. 49-73; Sjäjell, B.: Sustainable Value Creation Within Planetary Boundaries-Reforming Corporate Purpose and Duties of the Corporate Board, Sustainability 2020, 6245, p. 1-15; Strine, L.: Toward Fair and Sustainable Capitalism. A Comprehensive Proposal to Help American Workers, Restore 
of a corporate purpose defined through the narrow lens of shareholder wealth maximization model still prevails. Why is that?

First and most importantly, shareholder primacy, monumentally reflected in the Friedman doctrine, ${ }^{13}$ is being understood as a sort of "natural corporate law"14 and constitutes a true paradigm in the Kuhnian sense of this term. ${ }^{15}$ Outside of the academic debate, the shareholder value paradigm has evolved into a social norm internalized by those actors of the corporate world that play the lead role in translating the corporate purpose into corporate conduct: directors. ${ }^{16}$ This also holds for the so-called "enlightened shareholder value" approaches. In fact, they do not contribute any "light" to the sustainability problem as they only confirm the considerations of stakeholder interests in win-win scenarios, in which "doing good leads to doing well". ${ }^{17}$

Second, the proponents of a reconceptualization of the corporate purpose disagree on how the law should mirror such renewed concept, which causes the shareholder value paradigm to "hold on". While the shareholder value protectors are neatly organized and operate testudo-like, ${ }^{18}$ ideas on sustainable ways to define the corporate purpose are advocated by dispersed academic warriors. The recently published E\&Y Study on directors' duties and sustainable corpo-

Fair Gainsharing Between Employees and Shareholders, and Increase American Competitiveness by Reorienting Our Corporate Governance System Toward Sustainable Long-Term Growth and Encouraging Investments in America's Future, University of Pennsylvania Law School, Institute for Law and Economics, Research Paper No. 19-39; Sjåfjell, B.: Regulating for Corporate sustainability: Why the public-private divide misses the point, in: Choudhury, B., Petrin, M. (eds.): Understanding the company, Cambridge University Press, 2017, p. 145-165.

13 Friedman, M.: The Social Responsibility of Business is to Increase its Profits, The New York Times Magazine September 13, 1970; Friedman, M.: Capitalism and Freedom, University of Chicago Press, 1962.

14 Mayer, C.: Prosperity: Better business makes the greater good, Oxford University Press, 2018, p. 2.

15 Kuhn, T.: The Structure of Scientific Revolutions, University of Chicago Press, 1970.

16 Sneirson, J.: The history of shareholder primacy, from Adam Smith through the rise of financialism, in: Sjåfjell, B., Bruner C.: The Cambridge Handbook of Corporate Law, Corporate Governance and Sustainability, Cambridge University Press 2020, p. 76; Brakman Reiser, D.: Progress is Possible. Sustainability in US Corporate Law and Corporate Governance, in: Sjåfjell, B., Bruner, C. (eds.): The Cambridge Handbook of Corporate Law, Corporate Governance and Sustainability, Cambridge University Press 2020, p.138.

17 Mayer, C.: Prosperity: Better business makes the greater good, Oxford University Press 2018, p. 4.

18 In Ancient Roman warfare, the testudo or tortoise formation was a type of shield wall formation commonly used by the Roman Legions during battles, particularly sieges. 
rate governance ${ }^{19}$ serves as an illustration of the point at issue. The said study which explored the problem of short-termism as a pre-identified cause for unsustainable corporate behavior has been critically received by the academic community. ${ }^{20}$ This was mainly due to its obvious flaws in methodology and the inaccurate composition of the research question. The resulting academic responses displayed, that there is - at least amongst parts of the individuals forming the academic community - a consensus on the need to address the issue of sustainability in corporate law. However, the question of appropriate means to reach this goal remains unsolved. Challenges are not limited to identifying the content of potential law-making. In the EU context the transnational features of company law and thus questions on legislative competences against the background of differential national approaches and path-dependencies magnify the assortment of imaginable solutions. ${ }^{21}$ This makes the shareholder value paradigm thrive, just because it has been around for a long time and as a result - constitutes the default solution. As long as there is no sound proposal for a new standard, the old one will remain unshattered. Shareholderism also triumphs over stakeholderism because it is simple: it provides a clearcut monodimensional rule to be followed by directors. This is very convenient for directors, shareholders, and the courts. Integrating sustainability into the

19 E\&Y Study on directors' duties and sustainable corporate governance, [https://op.europa. eu/de/publication-detail/-/publication/e47928a2-d20b-11ea-adf7-01aa75ed71a1/language-en], accessed on 2.12.2020.

20 Roe, M., Spamann, H., Fried J. M., Wang, C. C. Y.: The European Commission's Sustainable Corporate Governance Report: A Critique, ECGI Law Working Paper No. 553/2020; Feedback Statement of the European Company Law Experts Group, [https://www.law. ox.ac.uk/business-law-blog/blog/2020/10/ec-corporate-governance-initiative-series-critique-study-directors], accessed on 2.12.2020; Feedback Statement from Bassen, A., Lopatta, K., Ringe, W-G.:, available: https://ec.europa.eu/info/law/better-regulation/have-your-say/ initiatives/12548-Sustainable-corporate-governance/F594615; Feedback Statement from Edmans A.: [https://ec.europa.eu/info/law/better-regulation/have-your-say/initiatives/12548-Sustainable-corporate-governance/F556360], accessed on 2.12.2020; Hansen, J. et. al: Response to the Study on Directors' Duties and Sustainable Corporate Governance by Nordic Company Law Scholars, Nordic \& European Company Law Working Paper No. 20-12; Coffee, J.: The European Commission Considers "Short-Termism" (And "What Do You Mean By That?"), [https://ecgi.global/news/european-commission-considers-\%E2\%80\%9Cshorttermism\%E2\%80\%9D-and-\%E2\%80\%9Cwhat-do-you-mean-\%E2\%80\%9D], accessed on 2.12.2020; Recordings and presentations from a dedicated series of workshops organized by the European Corporate Governance Institute can be found here: [https://ecgi.global/content/ directors $\%$ E2\% $80 \% 99$-duties-and-sustainable-corporate-governance\#! event-presentations], accessed on 2.12.2020.

21 Katelouzou, D., Zumbansen, P.: The New Geographies of Corporate Law Production, Transnational Law Institute, King's College London Research Paper Series No. 13/2020, available: [https://papers.ssrn.com/sol3/papers.cfm?abstract_id=3575009], accessed on 2.12.2020. 
corporate purpose and shaping corporate conduct in accordance is multifaceted and thus more complex to assess. ${ }^{22}$

Third, depending on the specific legal system being discussed, the arguments for a sustainability-influenced corporate purpose, on the one hand, may claim, that the binding corporate law allows for a renewed interpretation which would suffice to leave the shareholder value maximization model behind. On the other hand, it may be argued that positive action of the lawmaker is a prerequisite for a redefinition of the corporate purpose in corporate law. Both approaches are internal in their character as they assume, that the corporate purpose and the corporate action which are taken upon and according to its content, are measured against a pre-defined intra-corporate law rule. Both approaches assume that the trigger to reconceptualize the corporate purpose is to be located within the corporate law which serves as the source of understanding the notion of the corporate purpose. They rest upon the supposition, that a redefinition of the corporate purpose is solely dependent upon factors shaping the characteristics of the corporation as set out by corporate law. This reveals another reason for the shareholder value paradigm's persistent triumph: Even if one assumes the existence of a that corporate law-based obligation to establish a link between the corporate purpose and sustainability, the specific impulses to alter corporate conduct need to be developed by the corporation itself, i.e. from the directors as its decision-making actors. But since directors have internalized the shareholder value paradigm as a social norm an internally-triggered reversal of these such norms does not herald a fast-track passage from a sustainable corporate purpose in books to a sustainable corporate purpose in action.

The above assessed predicaments paint a rather gloomy scenario of a continued corporate purpose debate within the known and established framework. This observation of the tardiness of corporate law as regards the sustainability problem has led the author to auto-question, whether the current academic debate, being encapsulate in a corporate law framework of assessment, has been distracted from noticing the transformative social changes that are linked to the sustainability postulate. Maybe it is worth considering, if sustainability-driven changes in human values have already overtaken the corporate law academic debate? Did we miss the forest for the trees?

22 This has traditionally given rise to the "argument of many masters", i.e. the stakeholderism critique based on the contention, that the plurality of interests which have to be taken into account by directors causes them to "serve many masters" which effectively precludes a clear-cut expression of their duties and further hinders the enforcement of such "blurred" duties. 
Hence, as a matter of forced pragmatism, ${ }^{23}$ this paper seeks to propose a novel analytical angle for analysis which may readjust the settled debate's frame of reference. It is the author's intention to explore new "entry points" through which the sustainability postulate may penetrate the corporation. Consequently, this paper seeks to steer away from the internal, corporate-law-based perspective on reconceptualizing the corporate purpose. Instead, the analysis is focused on external but still private-law-driven impulses which may "push the corporation from the outside" to adopt sustainable corporate conduct. ${ }^{24}$ As a result, the paper places the sustainability challenge in a broader societal context and encourages reflecting, if the topic debated by corporate law scholars is, in fact, at least partially already decided by society at large. The author hypothesizes that while the academic community debates over conceptual internal perspectives on the corporate purpose, corporations as private-law actors may already be subject to significant constraints in determining their purpose and simply put - their actions. Therefore, light is to be shed on the external constraints that may elbow the sustainability postulate into corporate conduct.

The argument of this paper is developed in three stages. First, it delineates the concept of "safety valves" 25 which can be universally identified across European private law systems. Using Polish law as an example, the author shows how legal systems of private law are subjecting private autonomy to certain limitations in order to ensure its alignment with morality-driven social norms. Such systemic "safety valves", mostly introduced through so called "general clauses" refer to good morals (bones mores) and aim at matching the outcomes of private ordering with society's moral standards. As Safjan signaled already

23 The current debate on so called benefit corporations seems to be of a similar pragmatic nature. The diagnosis of a deadlock in reconceptualizing the corporate purpose has put life into „fresh" corporate vehicles for social entrepreneurship that serve as an escape from the seemingly untouchable shareholder value paradigm. On benefit corporations see: Liao, C.: Social Enterprise Law: Friend of Foe to Corporate Sustainability, in: Sjåfjell, B., Bruner, C. (eds.): The Cambridge Handbook of Corporate Law, Corporate Governance and Sustainability, Cambridge University Press 2020, p. 669-681; Alexander, F.: Benefit corporation law and governance, Oakland, 2018; contributions in: Means, B., Yockey, J. (eds.): The Cambridge handbook of social enterprise law, Cambridge University Press, 2018; Möslein, F.: Reformperspektiven im Recht sozialen Unternehmertums, ZRP 2017, 175.

24 As regards external stakeholder pressures on corporations which may influence corporate action towards social goals see: Buckley, P.: Can corporations contribute directly to society or only through regulated behaviour?, Journal of the British Academy, 6(s1), p. 323-374.

25 The author was inspired by the term „Notventil” used in German scholarship, e.g., by Schubert, C.: Münchener Kommentar zum BGB, 8. Auflage 2019, p. 94. 
in 1990, a crucial challenge within this interplay of private autonomy and values cultivated by society concerns environmental matters. ${ }^{26}$

The second part of the paper analyses how a sustainability-driven transformation of values within society may impact corporate conduct and subsequently lead to a forced, externally driven reconceptualization of the corporate purpose. A proposed theoretical framework build upon the safety valve concept is supported by the empirical assessment of available data. In that regard, the paper focuses on the environmental component of the sustainability postulate in order to discuss if societies are undergoing a transformative process that exhibits an "internalization" of sustainability-tinted ideas. The analysis allows for the preliminary conclusions that a profound transformation of values "towards sustainability" is currently already underway. The paper thus argues that the sustainability idea invades the corporation irrespective of which "internal" model of deciphering the corporate purpose we adopt. In other words, directors must consider sustainability issues in structuring their decisions and the resulting corporate conduct, as they will be subject to verification through the lens of a renewed set of values forming the notion of nowadays good morals. Accordingly, this paper's core argument states that the sustainability transformation of values within society reframes the understanding of good morals and thus delimits the way the corporate purpose and corporate conduct may be constructed ad casum by directors. Such a conclusion holds regardless of how we conceptualize the corporate purpose from an "internal" corporate law perspective. In the fourth section of this paper, these preliminary findings are confronted with connected enforcement challenges.

It must be stressed, that it is not the author's aspiration to claim the irrelevancy of the ongoing corporate law debate on the corporate purpose. On the contrary, reflection upon external impulses that may propel corporate conduct into a more sustainable direction stresses the urgency of a structured and joint effort to finally and effectively tackle the issue in corporate law. This paper aims at adding fuel to the ongoing discussion by spotlighting other, external paths through which sustainability may gain entrée to the corporation. It is consequently being argued, that the corporation not only should not be but already is not immune to the sustainability idea.

26 Safjan, M: Klauzule generalne w prawie cywilnym (przyczynek dodyskusji), Państwo i Prawo 11 1900, p. 53. 


\section{2. “SAFETY VALVES” IN EUROPEAN PRIVATE LAW}

\subsection{THE CONCEPT OF BONOS MORES AS A SAFETY VALVE IN PRIVATE LAW}

It seems legitimate to state that the necessity to bring private ordering into agreement with moral values of society is a prevalent idea in European private law systems. ${ }^{27}$ The concept of referencing legal acts to morality (bonos mores) can be traced back to Roman Law. ${ }^{28}$ The fundamental assumption is straightforward: Morality fences-in private autonomy. Legal acts should only be enforceable in court, if these boundaries are respected. It is generally understood that the enforcement of immoral acts by the courts would undermine the legal system's esteem. ${ }^{29}$ Therefore, private law systems apply safety valves - mainly in the shape of general clauses, which open these systems to extra-legal considerations revolving around moral and ethical values nurtured by society. Through the application of these non-legal criteria to assess private actor's behavior, the content of the law is "saturated" with values.

The content of what constitutes the moral standard may vary geographically across European countries, as values amongst the population differ. Most importantly, the substance of the bonos mores transforms over time. ${ }^{30}$ Behavior that may have been judged as immoral several years ago may not be subject to the same assessment today. If set out by legislation, the notion of bonos mores is usually used in the function of a general clause which purposefully leaves the determination of its content open and flexible over time. Similarly, in Common Law systems the judge's assessment of the so-called "policy of the law" remains adjustable to the circumstances. As stressed in Evanturel v. Evanturel $^{31}$ "The determination of what is contrary to the so-called "policy of the law" necessarily is subject to change over time. Many transactions are upheld now by our courts which a former generation would have avoided as contrary to the supposed policy of the law". The rule remains but its application varies with the principles which for the time being guide public opinion. In this

27 Zimmermann, R.: The Law of Obligations, Roman Foundations of the Civilian Tradition, Clarendon Press, 1996, p. 697-705; Zweigert, K., Kötz, H.: Introduction to Comparative Law, Oxford University Press, p. 380, 381.

28 Zimmermann, R.: The Law of Obligations, Roman Foundations of the Civilian Tradition, Clarendon Press, 1996, p. 706.

29 Zimmermann, R.: The Law of Obligations, Roman Foundations of the Civilian Tradition, Clarendon Press, 1996, p. 706.

30 Zimmermann, R.: The Law of Obligations, Roman Foundations of the Civilian Tradition, Clarendon Press, 1996, p. 714.

31 Eventurel v. Evanturel (1974) LR 6 PC I, 29. 
sense, the bonos mores serve as "adaptive clauses" which allow for a gradual, evolutionary transformation of private law. ${ }^{32}$ It follows that the content of the bonos mores is a reflection of what can be termed a ubiquitous moral attitude (position) within society. Consequently, the essence of the safety valve concept rests in the capability of private law to react upon altering outer circumstances which - if unaddressed - would lead to a harmful clash between the results of private ordering and the moral sentiments of society.

In general, most changes in moral attitudes of society over the last decades rather navigated in the direction of loosening and opening the notion of bonos mores to pluralistic viewpoints, consequently establishing a laxer verification standard. However, it needs to be noted that such orientation of development is not imperative. The possibility that society develops a very strong moral position regarding actions previously understood as permissible is equally possible. ${ }^{33}$

\subsection{THE PURIFYING FUNCTION OF BONOS MORES}

The most universally accepted and employed consequence of applying the safety valve concept based on the notion of bonos mores is the nullification of legal acts, in particular contracts. The idea of freedom of contract which emerged through the centuries is nowadays being justified on grounds of either the theory of private autonomy ${ }^{34}$ or in terms of the utilitarian notion of public benefit ${ }^{35}$ and cultivated across European private law systems. Nevertheless, private ordering is being constrained by lawmakers. The most obvious boundary is the black letter law. If a legal act - for example, the conclusion of a contract violates the law, European private law systems usually declare such action null

\footnotetext{
32 Safjan, M.: Klauzule generalne w prawie cywilnym (przyczynek dodyskusji), Państwo i Prawo 11 1990, s. 48-59.

33 Zimmermann, R.: The Law of Obligations, Roman Foundations of the Civilian Tradition, Clarendon Press, 1996, p. 714.

34 In line with such approach the fundamental function of legal systems is understood to be the protection of the freedom and self-determination power of the individual. As Flume put it: "The idea behind contract is that what has been agreed is binding because in making the contract the parties have agreed that it should determine their rights and liabilities" (Flume W.: Das Rechtsgeschäft, Springer, 1975, p. 7).

35 The utilitarian view states that the enforceability of contracts contributes to efficient societal outcomes because scarce goods and services are held by those who place the greatest value on them, see: Zweigert, K., Kötz, H.: Introduction to Comparative Law, Oxford University Press, p. 327.
} 
and void. ${ }^{36}$ An analogous consequence is commonly attributed to the immorality of legal acts. ${ }^{37}$ The concept of nullity of an immoral legal act originated in Roman Law, which sanctioned transactions contra bonos mores. ${ }^{38} \mathrm{~A}$ legal act is immoral when it offends against general contemporary ethical (moral) principles and attitudes. ${ }^{39}$ Bonos mores are therefore to be understood as values commonly accepted in our society, which are both a heritage and a component of European culture. ${ }^{40}$ Consequently, European private law regimes universally sanction the immorality of legal acts by declaring them null and void ex lege or enabling their nullification. ${ }^{41}$ It follows, that the concept of nullity "purifies" private ordering from its immoral elements (purifying function). The rules that determine nullity of a legal act in case of infringement of bonos mores may stem from either legislation or judicial decision but they "are all very much the same". ${ }^{42}$ The crucial task rests always with the judge, who has to decide whether the boundaries of private autonomy have been surpassed. ${ }^{43}$ Of course, the paramount puzzle lies in the necessity to determine what the content of the moral standards is, in order to inspect their possible violation.

As an example, in Polish private law, the general rule that allows for nullification of legal acts contra bonos mores is contained in Article $58 \S 2$ of the Polish Civil Code which states that "A legal act contrary to the principles of social

36 On illegality as reason for nullity in Roman Law see: Zimmermann, R.: The Law of Obligations, Roman Foundations of the Civilian Tradition, Clarendon Press, 1996, 1996, p. 697-705.

37 Zweigert, K., Kötz, H.: Introduction to Comparative Law, Oxford University Press, p. 381; Further on the notion of bonos mores in different European private law regimes: Kötz, $\mathrm{H}$ : Die Ungültigkeit von Verträgen wegen Gesetz- und Sittenwidrigkeit. Eine rechtsvergleichende Skizze, RabelsZ, 58 1994, p. 209; Simitis, K., Gute Sitten und Ordre Public, Elwert 1960; Bonnecase, J.: La Notion juridique de bonnes moerurs; sa portree en droit civil francais, Etudes a la memoire de Henri Capitant, Dalloz 1939, p. 91; Thommen, W.: Beitrag zur Lehre vom Begriff der guten Sitten im schweizerischen Privatrecht, Winterthur, 1954; Safjan, M.: Klauzule generalne w prawie cywilnym (przyczynek dodyskusji), Państwo i Prawo 11 1990, s. 48-59.

38 Zimmermann, R.: The Law of Obligations, Roman Foundations of the Civilian Tradition, Clarendon Press 1996, p. 706.

39 Cartwright, H.: The Law of Obligations in England and Germany: Some Comparative Reflections in the Light of the Proposals in Law Reform Now, The International Comparative Law Quarterly, 13 (4) 1964, p. 1326.

40 Radwański Z, Trzaskowski R., in: Radwański Z., Olejniczak A. (eds.), System Prawa Prywatnego, Prawo cywilne - część ogólna, C.H. Beck (Poland), p. 319.

${ }^{41}$ Zimmermann, R.: The Law of Obligations, Roman Foundations of the Civilian Tradition, Clarendon Press, 1996, p. 697-705; Zweigert, K., Kötz, H.: Introduction to Comparative Law, Oxford University Press, p. 380, 381.

42 Zweigert, K., Kötz, H.: Introduction to Comparative Law, Oxford University Press, p. 380.

43 Zweigert, K., Kötz, H.: Introduction to Comparative Law, Oxford University Press, p. 381. Further on the topic of enforceability see section 4 below. 
coexistence (zasady współżycia społecznego) ${ }^{44}$ is null and void". As regards contract law, this is further developed about the principle of freedom of contract which is spelled out in Article 353 of the Polish Civil Code. According to this provision, the contracting parties may establish their legal relationship according to their own discretion, as long as its content or purpose does not contradict the law, the nature of the relationship, or the principles of social coexistence. The discussed safety valve uses the notion of "principles of social coexistence" as a general clause that draws a content-boundary to private ordering. If such content-boundary is surpassed, the legal act is null and void and thus unenforceable in court.

The rule for nullification of legal acts contained in Article $58 \S 2$ of the Polish Civil Code applies to resolutions of the management board and the supervisory board of corporations. These resolutions are treated as legal acts in terms of the cited provision and are to be regarded as null and void if their content infringes bonos mores. The violation of the bonos mores by shareholder resolutions has been subject to separate regulation in Article $249 \S 1$ (limited liability company) and Article $422 \S 1$ (joint-stock company) of the Polish Code of Commercial Companies. According to these analogous provisions, a resolution of the general meeting contrary to the articles of association or good morals and detrimental to the company's interest or aimed at harming a shareholder may be appealed against by way of an action for the annulment. This means that an action for annulment cannot be solely based on the alleged infringement bonos mores. Such a premise must be met cumulatively with at least one other premise, being either harm to the company's interest or harm to a particular shareholder.

\subsection{THE CONTROLLING, SHAPING AND INTERPRETATIVE FUNCTION OF BONOS MORES}

As explained, the most omnipresent application of the concept of bonos mores in European private law rests in their purifying function which enables the nullification of immoral legal acts. The use of morality-driven safety valves is,

\footnotetext{
44 The term "principles of social coexistence" is understood to serve the purpose of a reference to bonos mores but at the same time it expands the notion of morality to the broader inclusion of ideological understandings of morality, which is characteristic for communist doctrines. Being thus a relic from communist times, nowadays the lawmaker has turned to the application of the general clause of good morals (good manners) "dobre obyczaje". See further: Malaurie, Ph.: L'ordre public et le contract, Etude de droit civil compare (France, Angleterre, URSS), Paris, 1967, p. 132; Safjan, M.: Klauzule generalne w prawie cywilnym (przyczynek dodyskusji), Państwo i Prawo 11 1990, s. 48-59.
} 
however, not limited to this purpose. Other variants of employing the bonos mores as a safety valve in private law may either limit the execution of rights by private actors (the controlling function), influence the content of legal acts (the shaping function) or determine the interpretation of declarations of will (the interpretative function). Using Polish private law as a blueprint for plausible similar applications across Europe, below the legal emanations of the said functions are shortly signaled.

The controlling function of bonos mores is mirrored in the concept of "abuse of law" (ger. Rechtsmissbrauch, fra. l'abus de droit). ${ }^{45}$ Article 5 of the Polish Civil Code states that one shall not execute one's right in violation of its socio-economic purpose or to the principles of social coexistence. Such an act of the right holder is not considered an exercise of the right and does not enjoy protection. Here, the general clause of bonos mores (principles of social coexistence) "controls" the manner in which rights are executed by their holders. If such execution violates bonos mores, enforcement by the courts will not be granted. The application of the abuse of right concept does not "destroy" the abused right and is therefore of a dilatory rather than peremptory nature. The dismissal of action regarding the bonos mores general clause may therefore be - due to changing circumstances - of a temporary character.

The shaping function of the bonos mores general clause is mirrored in Article 56 of the Polish Civil Code. As stated in this provision, a legal act produces not only the effects expressed in it but also those resulting from the law, from the principles of social coexistence and established customs. This means that the content of a legal act is shaped not only by the declaration of will but also by other normative factors. Alongside the law and established customs, the bonos mores constitute one of such normative factors. It follows, that unlike in the case of nullification, the shaping function of the bonos mores does not set boundaries for the permissible content of the legal act but seeks to co-define it. As the bonos mores may supplement the content of the legal act they place the legal act in a certain social and moral context. ${ }^{46}$

The interpretative function of the bonos mores is reflected in Article $65 \S 1$ of the Polish Civil Code which states that a declaration of will should be interpreted as required by the circumstances in which it was made, the principles of social coexistence and established customs. This shows that the interpretation

\footnotetext{
45 The concept of abuse of right is prevalent in continental private law regimes. The power of the judge in the common law system to diverge from the rule of the precedent in order o address the specific facts of the case substitutes this instrument in common law systems.

46 Safjan, M.: Kodeks cywilny, Vol. I, Online Commentary to Art. 56, sec. 31, C.H. Beck, 2020 .
} 
of declarations of will is not subject to the arbitrary assessment of the declarant, but depends in the given circumstances on external objectified criteria, in particular extra-legal notions of morality expressed through the general clause of principles of social coexistence. ${ }^{47}$ The emerging process of interpretation should analyze the bonos mores against the background of the specific factual circumstances in which the declaration of will was made. The interpretative application of the bonos mores must therefore be sufficiently individualized. ${ }^{48}$

\section{SUSTAINABILITY - TOWARDS A NEW CORPORATE MORALITY?}

\subsection{TRANSFORMATION OF VALUES}

As revealed by the above analysis, safety valves in private law aim at aligning the outcomes of private ordering with morality. Their design accommodates the transformation of the understanding of morality over time and allows for a running "update" of the legal framework according to the values cultivated by society. It follows, that the process of applying morality-driven safety valves requires the performance of a "value discovery". Values are cognitive constructs developed in the minds of individuals. They are to be understood as the content that shapes the understanding of morality. The aggregate (collective) occurrence of values within society may lead to the formation of social norms. These social norms represent crystalized values which have taken the shape of established rules of behavior humans feel obligated to follow ${ }^{49}$.

As already noted above (sec. 2.1), values do not hibernate in a status quo. On the contrary, they are susceptible to change. In fact, the very essence of the safety valves' function presupposes such change. Answers on what triggers

\footnotetext{
47 Safjan, M.: Kodeks cywilny, Vol. I, Online Commentary to Art. 56, sec. 5, C.H. Beck, 2020 .

48 Safjan M.: Kodeks cywilny, Vol. I, Online Commentary to Art. 56, sec. 5- 6, C.H. Beck, 2020.

49 Extensively on the nature of social norms: Hume, D.: A Treatise of Human Nature, Oxford University Press, [1739] 1978; Sunstein, C.: Social Norms and Social Roles, Columbia Law Review, 96 1996, p. 904; McAdams, R. H.: The Origin, Development, and Regulation of Norms, Michigan Law Review 96 1997, p. 338; Lewis, D.: Convention: A Philosophical Study, Cambridge MA, Harvard University Press, 1969; Posner E.: Law and Social Norms, Cambridge MA, Harvard University Press, 2000; Ullmann-Margalit E.: The Emergence of Norms. Oxford University Press, 1977; Sugden, R.: The Economics of Rights, Cooperation and Welfare, Oxford, Basil Blackwell, 1986; Young, P.: The evolution of conventions, Econometrica, 611993 , p. 57-84; Bicchieri, C.: The Grammar of Society: The Nature and Dynamics of Social Norms. New York, Cambridge University Press, 2006.
} 
value transformation must be sought outside of the legal sciences. An adequate recapitulation would exceed the scope of this paper by far. For the purpose of signaling one of the many theoretical approaches to the transformation of values, it is nevertheless worth mentioning, that according to the conservation biology literature, values are the result of human adaptation to different social and environmental contexts ${ }^{50}$. The adaptation process occurs in relation to biologically based needs, social interaction, and group welfare and survival ${ }^{51}$. Within societies, "values change is an evolutionary process in which those values that are best suited to cope with life under given existential conditions have a selective advantage". ${ }^{52}$ Transformative changes of values often occur in relations to significant social-ecological developments, including in particular ecological disasters. ${ }^{53}$ It follows, that humans' values, as part of their cognitive structures, are subject to an adaptive process. ${ }^{54}$ As summarized by Manfredo et al. "The nature of values is rooted in their adaptive function, so the nature of value change is likely to reflect an adaptive function as well". ${ }^{5}$

\subsection{THE EMPIRICS}

The conclusion that European private law is capable of "updating" itself in reference to the transformation of values within society, paired with the proposition that environmental deterioration may potentially trigger such value changes, raises the question about empirical proof. It is critical to inspect whether the sustainability postulate reshapes values within society, and the social norms build thereupon, to an extent that substantiates the reconceptualization of the

50 Manfredo, M. et al.: Why social values cannot be changed for the sake of conservation, Conservation Biology, Volume 31, No 4, 2017, p. 776 and the empirical studies listed therein.

${ }_{51}$ Schwartz, S.H., Bilsky, W.: Toward a theory of the universal content and structure of values: extensions and cross-cultural replications, Journal of Personality and Social Psychology, 58 1990, p. 878- 891.

52 Inglehart, R., Welzel R.: Modernization, cultural change, and democracy: the human development sequence, Cambridge University Press, Cambridge, 2005, p. 23.

53 Manfredo, M. et al.: Why social values cannot be changed for the sake of conservation, Conservation Biology, Volume 31, No 4, 2017, p. 778. For a study on how independence values emerged in the United States see: Kitayama, S., Conway, L., Pietromonaco, P., Park, H., Plaut, V.: Ethos of independence across regions in the United States: the production-adoption model of cultural change, American Psychologist 65 2010, p. 559-574.

54 Manfredo, M. et al.: Why social values cannot be changed for the sake of conservation, Conservation Biology, Volume 31, No 4, 2017, p. 776.

55 Manfredo, M. et al.: Why social values cannot be changed for the sake of conservation, Conservation Biology, Volume 31, No 4, 2017, p. 776. 
notion of morality. This question calls for dedicated empirical studies. ${ }^{56}$ There is a great need for collaborative research to identify, measure, and explain the development values related to sustainability over time. ${ }^{57}$ Ideally, this research should integrate survey, ethnographic, historical, and experimental methods. ${ }^{58}$ Remarkably, the question of how the idea of sustainable development translates into human values has not been asked directly in empirical research yet. ${ }^{59}$ However, there are numerous studies available that assess how society relates to specific principles or aspects of what constitutes the concept of sustainability. Consequently, in the absence of empirical data derived from a tailor-made study, preliminary findings that constitute a hypothesis for further research should be derived from the available data on fragmented questions which are indicative for a potential sustainability-induced value transformation. Hence, as an interim measure, this paper analyses existing, available data that illuminates how the sustainability idea influences Europeans' values. These vital indicators for a value transformation towards sustainability are the personal concern of humans with environmental problems, the viewpoint on humans' interaction with nature (the "mastering vs. of coexistence" question), and the attitudes towards environmental policies.

As regards the subject of environmental concern, studies are mainly produced within the environmental sociology domain which deals with the question of how environmental risks are perceived by society. ${ }^{60}$ Fundamental findings may be derived from the Special Eurobarometer 501 Report "Attitudes of European citizens towards the Environment" that was requested by the European Commission Directorate-General for Environment and coordinated by the Directorate-General for Communication (the "Eurobarometer Report"). ${ }^{61}$ The data set is fairly up-to-date as fieldwork for the said report was conducted in December 2019, publication occurred in March 2020. The public opinion survey was conducted in all European Union Member States. 274998 EU citizens from different social and demographic categories were interviewed at home in their native language. According to the key findings of the Eurobarometer Re-

\footnotetext{
56 Being directly endeavoured by the author in the near future.

57 Leiserowitz, A., Kates, R., Parris, T.: Do Global Attitudes and Behaviors Support Sustainable Development?, Environment, 47(9) 2005, p. 37.

58 Leiserowitz, A., Kates, R., Parris, T.: Do Global Attitudes and Behaviors Support Sustainable Development?, Environment, 47(9) 2005, p. 37.

59 To the author's best knowledge.

60 Franzen, A., Vogl, D.: Umweltbewusstsein und der Reichtum von Nationen: Ein Vergleich von WVS, ISSP und EVS, in: Beckers T., Birkelbach K., Hagenah J., Rosar U. (eds): Komparative empirische Sozialforschung, 2010, VS Verlag für Sozialwissenschaften, p. 338.
}

${ }_{61}$ Eurobarometer Report "Attitudes of European citizens towards the Environment", [https:// ec.europa.eu/commfrontoffice/publicopinion/index.cfm/Survey/getSurveyDetail/instruments/ SPECIAL/surveyKy/2257], accessed on 2.12.2020. 
port, more than nine in ten respondents (94\%) say that protecting the environment is important to them personally; including just over half $(53 \%)$ who say it is very important. What is interesting, the data shows very little variation in responses classified by socio-demographic groups: gender, age or education or occupation do not substantially impact the findings. Around three-quarters of Europeans (76\%) think that climate change is a very serious problem in their country at the moment, and a similar proportion (77\%) see it as a very serious problem in the EU as a whole. Another key finding is that there is widespread concern about the impact of environmental issues on respondents' daily life and on their health. More than three quarters of Europeans (78\%) agree that environmental issues have direct effect on their daily life and their health. The present low trust in business ${ }^{62}$ is visibly reflected in Europeans' assessment of corporations' environmental endeavors. Four in five respondents $(80 \%)$ say that big corporations are not doing enough to protect the environment. An earlier survey on environmental concern from the year 2000 which examined developed and developing countries found that $83 \%$ of all respondents were concerned about environmental problems. ${ }^{63}$

Another fruitful indicator of sustainability-fueled value transformation maybe found in the analysis of the most basic question regarding the human-nature relationship, i.e. whether humans should master nature or should rather coexist with nature. As studies show, the viewpoint according to which humans master nature is being increasingly rejected. ${ }^{64}$ The 2000 World Values Survey found that $76 \%$ of respondents across 27 countries declared that humans should coexist with nature. ${ }^{65}$ These quotas are much higher amongst Europeans, Japanese, and North Americans ranging from 85\% advocating the "coexistence thought" in the United States to $96 \%$ of proponents of it in Japan. ${ }^{66}$

62 Mayer, C.: Prosperity: Better business makes the greater good, Oxford University Press 2018, p. 8 .

63 Data from Environics International (Globe Scan), Environics International Environmental Monitor Survey Dataset (Kingston, Canada: Environics International, 2000), http://jeff-lab. queensu.ca/ poadata/info/iem/iemlist.shtml (accessed 5 October 2004).

64 Leiserowitz, A., Kates, R., Parris, T.: Do Global Attitudes and Behaviors Support Sustainable Development?, Environment, 47(9) 2005, p. 25.

65 Data from World Values Survey, The 1999-2002 Values Surveys Integrated Data File 1.0, CD-ROM in: Inglehart, R., Basanez M., Diez-Medrano J., Halman L., Luijkx R. (eds)., Human Beliefs and Values: A Cross-Cultural Sourcebook Based on the 1999-2002 Values Surveys, first edition, Mexico City, 2004 .

66 Data from World Values Survey, The 1999-2002 Values Surveys Integrated Data File 1.0, CD-ROM in: Inglehart, R., Basanez, M., Diez-Medrano, J., Halman, L., Luijkx, R. (eds)., Human Beliefs and Values: A Cross-Cultural Sourcebook Based on the 1999-2002 Values Surveys, first edition, Mexico City, 2004 . 
Potent conclusions may also be drawn from the attitudes of humans as regards policy-making. ${ }^{67}$ The aforementioned Eurobarometer report revealed the respondents' expectations as regards EU-legislation: Around four in five (83\%) agree that EU environmental legislation is necessary for protecting the environment in their country, while a similar portion agrees that the EU should assist non-EU countries to improve their environmental standards. As another example, according to a study from the year 2000, global society's backing for bolder environmental protection regulation was proven with a $69 \%$ quota of respondents claiming that their national laws and regulations were insufficient. ${ }^{68}$ Similarly, in a study from the year 2001, $79 \%$ of respondents from G8 countries criticized the efficiency and pace of advancement in international negotiations and thus the progress on climate change as either "not good enough" (39\%) or "not acceptable" (40\%)". 69

It requires stressing, that the above-described intention to empirically capture the sustainability-induced value transformation is not a constituent element of the safety valve concept. The effort performed herein to sketch the transformation of values based on diverse indicative data serves the purpose of substantiating the theoretical claim of this paper. The application by a judge does not necessitate in her explicit reference to any empirical evidence which would prove the existence of a given standard of morality. Regardless of what moral standard is being scrutinized by the judge, the existence of a dedicated empirical study that would serve as a yardstick for his assessment would rather be the exception than the rule. The lack of a dedicated set of data does not imply that judicial assessments of morality-driven general clauses cannot be performed.

\subsection{THE IMPACT ON CORPORATE CONDUCT}

The above allows to formulate a preliminary conclusion, that empirical data - though not derived from bespoke studies - confirms that the sustainability postulate in being mirrored in values cultivated by Europeans. The emanation of these values in social norms should consequently be capable of shaping the understanding of the notion of morality. In other words, the assessment of a

67 Leiserowitz, A., Kates, R., Parris, T.: Do Global Attitudes and Behaviors Support Sustainable Development?, Environment, 47(9) 2005 45-72.

68 Environics International (GlobeScan), Environics International Environmental Monitor Survey Data set, Kingston, Canada, Environics International, 2000, [http://jeff-lab.queensu. ca/poadata/info/iem/iemlist.shtml], accessed on 2.12.2020.

69 Environics International (GlobeScan), New Poll Shows G8 Citizens Want Legally-Binding Climate Accord, Toronto, Environics International, 2001, [http://www.globescan.com/news_ archives/IEM_climatechange.pdf], accessed on 2.12.2020. 
given behavior in light of these sustainability-tinted social norms could reveal their infringement. This in turn suggests, that the transformation of the content of the bonos mores and the resulting morality judgements may "activate" the herein analyzed functions of the private law safety valves.

Bridging over to the specific context of corporate conduct, corporations as private actors are naturally "covered" by the functions of the said private law safety valves. Corporate conduct which falls within the scope of private law regimes is thus subject to the potential impact of a safety valve's "activation" that occurs due to a morality judgment stemming from sustainability-based values. When recapitulating the safety valves' functions deciphered above, it becomes evident that values, which encapsulate the sustainability idea and reshape morality assessment, may significantly influence corporate conduct.

The influence of the safety valves' purifying and controlling functions on corporate conduct may be twofold. First, legal acts undertaken by the corporation as a separate entity and an actor within private law regimes may become the subject to verification against the bonos mores. Simply put, each legal act performed by the corporation is potentially at risk of being challenged on grounds of a new morality standard which includes sustainability considerations. Hence, as an example, a contract on a corporation's chemical waste disposal may be subject to sustainability-guided scrutiny and turn out to be unenforceable in court. Second, nullification substantiated by the violation of a sustainability-adjusted morality standard may affect resolutions of the management board, the supervisory board and the general meeting. Though the specific character of these inner-corporate legal acts may vary, some certainly have a key impact on shaping corporate conduct. For instance, a resolution of the management board may emulate the choice of a contractor which is to be commissioned with the corporation's chemical waste disposal in a way that clashes with standards of sustainable behavior. It follows that for the avoidance of the hazard of nullification or - put more precisely - the risk of refusal of enforcement, corporate conduct should be designed in anticipation of potential sustainability-channeled scrutiny. Corporate conduct is shaped according to corporate business strategies which in turn reflect the understanding of the corporate purpose. If there are sustainability-based limits to the corporate conduct's content, the liberty to fame business strategies and - as a consequence - to define the corporate purpose, is being restraint. Consequently, when corporate actors realize, that decisions violating sustainability standards may be judged contra bonos mores, corporate conduct is likely to be altered, dovetailing also changes in the understanding of the corporate purpose. As a result, the sustainability postulate invades the corporation and its purpose by means of external content-boundaries to corporate conduct. 
The safety valves' shaping and interpretative functions may exert an impact upon a corporation's legal act's content. As a normative factor, sustainability considerations embedded in the bonos mores standard may supplement the content of a legal act that was undertaken by a corporation beyond what follows from its declaration of will (shaping function) or serve as a yardstick for interpreting such declaration of will (interpretative function). This means that the content of legal acts which "materialize" corporate conduct may be externally shaped by the sustainability postulate. The mandatory influence of sustainability ideas on corporate conduct may in turn have a reflexive and in fact coercive effect upon a given corporation's notion of its purpose. To that end, the safety valves' shaping function creates an opening wedge for the sustainability postulate to autonomously influence corporate conduct, i.e. even without any necessary "action" of corporate actors.

\section{OBSTACLES TO A NEW CORPORATE MORALITY - THE ENFORCEMENT CONUNDRUM}

Thus far, the analysis of safety valves was focused on their potential material applicability under the empirically sound assumption that the bonos mores are in a state of a sustainability-transformation. It was concluded, that safety valves embedded in private law regimes may clear the paths for sustainability to invade the corporation and trigger changes of corporate conduct. What has not been subject to investigation yet is the fundamental question on enforcement of the sustainability-propelling safety valve concept.

The influence of the safety valves' functions on corporate conduct as explained in sec. 3.3 will only be triggered if the corporation's legal act, the corporate body's resolution or its declaration of will be brought before a court and in order to become the subject of judicial assessment. In consequence, there are two premises that need to be satisfied for the safety valve concept to have not only a theoretical allure but also a practical meaning. First, judicial assessment must be enabled through the initiation of proceedings (the initiation obstacle). Second, such judicial assessment must be carried out in a way that takes the sustainability driven changes of morality into account (the execution obstacle).

The initiation obstacle stems from the nature of the private law relationship. In general, only the parties to a given relationship have the procedural means to get the ball rolling and create the opportunity for application of the discussed safety valves through judicial review. ${ }^{70}$ In the case of contracts concluded by

70 Rühmkorf, A.: Stakeholder Value versus Corporate Sustainability. Company Law and Corporate Governance in Germany, in: Sjåfjell, B., Bruner, C. (eds.): The Cambridge Hand- 
corporations, the typical circumstances would be an enforcement claim filed by one of the parties. In Polish law, declaratory claims, which would encompass the safety valves' application, can theoretically be brought by anyone who has a legitimate interest. By cause of the narrow understanding of such legitimate interest, the potential circle of eligible claimants remains very limited. As regards resolutions of the general meeting, the herein explored example of Polish law specifies a narrow catalogue of entities directly involved in the corporate relationship, which may bring a claim for annulment. ${ }^{71}$ The law does not designate the persons who have standing in claims for annulment of management board and supervisory board resolutions. As a result, the regular rules on legitimacy of interest to bring a claim forward are applicable and lead again - to a narrow group of persons entitled to bring an action. This compels to conclude that as long as the parties to the private law relationship (even in the broader context of a corporation's body's resolution) are not in dispute over its content there will simply be no occasion for judicial assessment.

The execution obstacle stems from the fact that the application of the safety vales in private law always involves judicial assessment. The judge's task in that regard is a difficult one. First of all, she needs to determine the standard of morality applicable in the given circumstances. In order to include sustainability considerations in her assessment, the judge personally would need to be open to investigate the value-transforming effects of sustainability and adopt a corresponding moral standard of review. An initial challenge lays in the necessity to recognize that the set of social norms internalized by corporate actors (in particular directors), which mirror the shareholder value paradigm, do not constitute the moral standard of review. Corporate actor's social norms are not to be regarded as he proper point of reference for applying safety valves whose ratio aims at aligning private ordering with values nurtured broadly in society and not by a narrow group of individuals or - even more so - the single individual who undertakes the legal act in question. The emerging problem is

book of Corporate Law, Corporate Governance and Sustainability, Cambridge University Press, 2020, p. 236.

71 The right to bring an action is vested in: the management board; the supervisory board; any member of the management and the supervisory board; a shareholder who voted against the resolution and, following its adoption, requested that her objection be recorded; a shareholder who, without valid reason, was not allowed to participate in the general meeting; a shareholder who was not present at the general meeting, however, only if the general meeting was wrongly convened or where the resolution concerned a matter not included on the agenda; in the case of a written vote, a shareholder who was overlooked at the vote or who did not consent to a written vote or who voted against the resolution and lodged an objection within two weeks of receiving notice of the resolution. 
well recognized and described as the attitude-behavior gap. ${ }^{72}$ In short, there are serious gaps between what people believe and what people do, in particular in European countries very strong pro-environmental attitudes are not accompanied by an equally strong readiness to act upon such attitudes.$^{73}$ Even though the judge may be capable of deciphering the sustainability induced morality shift, she may feel reluctant to actually put such value assessment into action. Such probable hindrances to enforcing new, transformative morality standards (whatever their content is) may particularly be present in the court as the judge's work environment which is - cautiously formulated - usually not prone to breaking new grounds.

In spite of the enforcement obstacles outlined above, one needs to stress, that limited enforcement does not necessarily imply a complete inefficiency of the outlined concept. Even the rare imposition of sustainability-driven boundaries upon corporate conduct through the application of safety-valves in the process of judicial review may have substantial impact. This should be attributed to a probable spill-over effect of such forerunner-judgements. They carry an important "signaling power" which demonstrates that sustainability issues could potentially be considered in the process of judicial review. Put differently, even if corporate conduct is only occasionally being delimited based on sustainability-driven moral standards, other market participants will be alerted. The powerful information voltage may consequently push other corporations (their directors) to reconsider and restructure their business strategies and its outcomes. What is more, the spill-over effect may evolve into a snowball effect which consists in the increase of court cases being filed or argued with reference to the safety-valves' capacity to translate sustainability postulates into enforceable moral standards.

An interesting example of the described informational imprint upon the general public may be derived from a neighboring field of "environmental litigation". Recently in Poland, one could observe a very lively media discussion about court judgments that found the State Treasury liable for infringing a personal right (personal interest) through the lack of a suitable action which

\footnotetext{
72 Blake, J.: Overcoming the 'Value-Action Gap' in Environmental Policy: Tensions Between National Policy and Local Experience, Local Environment, 4(3) 1999, p. 257-78; Kollmuss, A. and Agyeman, J.: Mind the Gap: Why Do People Act Environmentally and What Are the Barriers to Pro-Environmental Behavior? Environmental Education Research, 8(3) 2002, p. 239-60; Stern, P. C.: Toward a Coherent Theory of Environmentally Significant Behavior," Journal of Social Issues 56(3) 2000, p. 407-424.

73 Qiuhua, L., Wang B., Deng H., Yu C.: A quantitative analysis of global environmental protection values based on the world values survey data from 1994 to 2014, Environmental Monitoring and Assessment 190, 2018, p. 593.
} 
would be aimed at protecting the environment. ${ }^{74}$ In these cases, the aggrieved parties were awarded damages that were supposed to compensate for the violation of the personal right to a clean environment. Though the numerical scale of these judgments may not be astonishing, the informational impact upon society was significant. Similarly, an analysis of the Norwegian Hempel cases concerning corporate group liability has prompted Sjäjjell to identify the potential of courts to act as "environmental champions". ${ }^{75}$ Such a role could result in stimulating a greater environmental awareness and sense of responsibility in the business world as corporations could be incentivized to internalize the environmental costs of their business activity and thus disincentivize them to set up choose group structures aimed at the avoidance of environmental liability. ${ }^{76}$

\section{CONCLUSION}

The paper establishes an alternative theoretical framework for investigating whether and how pressing sustainability challenges may exert an impact upon the notion of the corporate purpose. The central claim is that the transformation of values cultivated by society is capable of "externally" inducing sustainability-driven changes to corporate conduct, which may reflexively modify the understanding of the corporate purpose. It is argued that the concept of safety valves embedded in private law regimes enables values fostered within society to invade private ordering. Hence, the corporation's autonomy in designing its conduct and the legal acts resulting therefrom is fenced-in by standards of morality (bonos mores).

The theoretical framework is supported by empirical evidence gathered from available data. Based on these indicative empirical findings one can assume that transformative changes in human values towards sustainability objectives are underway.

Based on the examination of enforcement hindrances the paper argues that even "numerically" limited enforcement carries important signaling power and may lead courts to exercise the functions of agents to sustainability-embracing change.

74 Judgment of the Regional Court for the City Warsaw, District Śródmieście, dated 24.01.2019, VI C 1043/18; Judgment of the Regional Court for the City Warsaw, District Śródmieście, dated 1.10.2019 r, II C 661/19.

75 Sjåfjell, B.: The Courts as Environmental Champions: The Norwegian Hempel Cases, European Company Law, 13(5) 2016, p. 199-206.

76 Sjåfjell, B.: The Courts as Environmental Champions: The Norwegian Hempel Cases, European Company Law, 13(5) 2016, p. 206. 
The preliminary conclusions reached in this paper call for extended in-depth research. In particular, a dedicated study of the sustainability-induced value transformation within society seems imperative.

In light of the current debate on the corporate purpose this paper sought to extend the area of academic investigation from a narrow corporate law perspective to institutions of general private law. Having diagnosed the perpetual character and a threatening deadlock of the discussion among corporate law scholars, which does not promise rapid outcomes, it was the author's intention to enrich the corporate purpose debate by a novel approach. Chiefly, the paper wishes to provoke the contemplation on whether it is actually up to the corporate law centered debate to decide how the corporate purpose should be defined. This paper urges to consider the possibility that the notion of the corporate purpose as perceived by society at large is already being subject to a profound value transformation towards sustainability and the corporate law debate is not to be considered as a driver of this process. This realization could bring about a denouement of the Gordian knot of the stakeholder v. shareholder primacy dispute and refocus the academic corporate law discussion on issues of legal design which would translate the "externally" reconceptualized corporate purpose into corporate law. It goes without saying that the ultimate consequences of the incompatibility of corporate law regimes with societal values would be deeply harmful.

\section{LITERATURE}

1. Alexander, F.: Benefit corporation law and governance, Oakland, 2018.

2. Bebchuk, L., Kastiel K., Tallarita R., For whom corporate leaders bargain, Working Draft, [https://papers.ssrn.com/sol3/papers.cfm?abstract_id=3677155], accessed on 2.12.2020.

-DOI: https://doi.org/10.2139/ssrn.3677155

3. Bebchuk, L., Tallarita R.: The Illusory Promise of Stakeholder Governance, Working Draft, [https://papers.ssrn.com/sol3/papers.cfm?abstract_id=3544978], accessed on 2.12.2020.

-DOI: https://doi.org/10.2139/ssrn.3544978

4. Berle, A.: Corporate Powers as Powers of Trust, Harvard Law Review 44, 1931, p. 1049.

-DOI: https://doi.org/10.2307/1331341

5. Berle, A.: For Whom are corporate managers trustees: A note, Harvard Law Review 45, 1932, p. 1365.

-DOI: https://doi.org/10.2307/1331920 
6. Bicchieri, C.: The Grammar of Society: The Nature and Dynamics of Social Norms, New York, Cambridge University Press, 2006.

-DOI: https://doi.org/10.1017/CBO9780511616037

7. Blake, J.: Overcoming the 'Value-Action Gap' in Environmental Policy: Tensions Between National Policy and Local Experience, Local Environment, 4(3) 1999, p. $257-78$.

-DOI: https://doi.org/10.1080/13549839908725599

8. Bonnecase, J.: La Notion juridique de bonnes moerurs; sa portree en droit civil francais, Etudes a la memoire de Henri Capitant, Dalloz 1939, p. 91.

9. Brakman Reiser, D.: Progress is Possible. Sustainability in US Corporate Law and Corporate Governance, in: Sjåfjell, B., Bruner, C. (eds.): The Cambridge Handbook of Corporate Law, Corporate Governance and Sustainability, Cambridge University Press 2020, p.138.

-https://doi.org/10.1017/9781108658386.016

10. Brundtland Report „Our Common Future” from 1987, [http://www.un-documents.net/our-common-future.pdf], accessed on 2.12.2020.

11. Buckley, P.: Can corporations contribute directly to society or only through regulated behaviour?, Journal of the British Academy, 6(s1), p. 323-374.

-DOI: https://doi.org/10.5871/jba/006s1.323

12. Cartwright, H.: The Law of Obligations in England and Germany: Some Comparative Reflections in the Light of the Proposals in Law Reform Now, The International Comparative Law Quarterly, 13 (4) 1964, p. 1326.

-DOI: https://doi.org/10.1093/iclqaj/13.4.1316

13. Choudhury, B., Petrin, M.: Corporate Duties to the Public, Oxford University Press, 2019.

-DOI: https://doi.org/10.1017/9781108377072

14. Coffee, J.: The European Commission Considers "Short-Termism" (And "What Do You Mean By That?"), [https://ecgi.global/news/european-commission-considers-\%E2\%80\%9Cshort-termism\%E2\%80\%9D-and-\%E2\%80\%9Cwhat-doyou-mean-\%E2\%80\%9D], accessed on 2.12.2020.

15. Cognac P-H.: The reform of articles 1833 on social interest and 1835 on the purpose of the company if the French Civil Code: Recognition or Revolution, in: Festschrift für Karsten Schmidt zum 80. Geburtstag, C.H. Beck, 2019, p. 213-221.

16. Data from Environics International (Globe Scan), Environics International Environmental Monitor Survey Dataset (Kingston, Canada: Environics International, 2000), [http://jeff-lab.queensu.ca/ poadata/info/iem/iemlist.shtml], accessed 2.12.2020).

17. Data from World Values Survey, The 1999-2002 Values Surveys Integrated Data File 1.0, CD-ROM in: Inglehart, R., Basanez M., Diez-Medrano J., Halman L., Luijkx R. (eds)., Human Beliefs and Values: A Cross-Cultural Sourcebook Based on the 1999-2002 Values Surveys, first edition, Mexico City, 2004. 
18. Dodd, E. M.: For Whom are corporate managers trustees?, Harvard Law Review 45, 1932, p. 1145.

-DOI: https://doi.org/10.2307/1331697

19. Eurobarometer Report "Attitudes of European citizens towards the Environment”, [https://ec.europa.eu/commfrontoffice/publicopinion/index.cfm/Survey/ getSurveyDetail/instruments/SPECIAL/surveyKy/2257], accessed on 2.12.2020.

20. E\&Y Study on directors' duties and sustainable corporate governance, [https:// op.europa.eu/de/publication-detail/-/publication/e47928a2-d20b-11ea-adf701aa75ed71a1/language-en], accessed on 2.12.2020.

21. Environics International (GlobeScan), Environics International Environmental Monitor Survey Data set, Kingston, Canada, Environics International, 2000, [http://jeff-lab.queensu.ca/poadata/info/iem/iemlist.shtml], accessed on 2.12.2020.

22. Environics International (GlobeScan), New Poll Shows G8 Citizens Want Legally-Binding Climate Accord, Toronto, Environics International, 2001, [http:// www.globescan.com/news_archives/IEM_climatechange.pdf], accessed on 2.12.2020.

23. Feedback Statement from Bassen, A., Lopatta, K., Ringe, W-G.:, https://ec.europa.eu/info/law/better-regulation/have-your-say/initiatives/12548-Sustainable-corporate-governance/F594615, accessed on 2.12.2020.

24. Feedback Statement from Edmans, A.: [https://ec.europa.eu/info/law/better-regulation/have-your-say/initiatives/12548-Sustainable-corporate-governance/ F556360], accessed on 2.12.2020.

25. Feedback Statement of the European Company Law Experts Group, [https://www. law.ox.ac.uk/business-law-blog/blog/2020/10/ec-corporate-governance-initiative-series-critique-study-directors], accessed on 2.12.2020.

26. Fisch, J., Solomon, S.: Should Corporations have a Purpose?, Law Working Paper No. 510/2020.

-DOI: https://doi.org/10.2139/ssrn.3561164

27. Fleischer, H.: Unternehmensinteresse und intérêt social: Schlüsselfiguren aktienrechtlichen Denkens in Deutschland und Frankreich, ZGR 2018, p. 703-734.

-DOI: https://doi.org/10.1515/zgr-2018-0031

28. Flume, W.: Das Rechtsgeschäft, Springer, 1975, p. 7.

-DOI: https://doi.org/10.1007/978-3-322-90070-8_1

29. Franzen, A., Vogl, D.: Umweltbewusstsein und der Reichtum von Nationen: Ein Vergleich von WVS, ISSP und EVS, in: Beckers T., Birkelbach K., Hagenah J., Rosar U. (eds): Komparative empirische Sozialforschung, VS Verlag für Sozialwissenschaften, 2010 , p. 338.

-DOI: https://doi.org/10.1007/978-3-531-92472-4_13 
30. Friedman, M.: Capitalism and Freedom, University of Chicago Press, 1962.

31. Friedman, M.: The Social Responsibility of Business is to Increase its Profits, The New York Times Magazine September 13, 1970.

32. Gelter, M.: Taming or Protecting the Modern Corporation? Shareholder-Stakeholder debates in a comparative light, NYU Journal of Law and Business 7(2), 2011, p. 642-730;

33. Hansen, J. et. al.: Response to the Study on Directors' Duties and Sustainable Corporate Governance by Nordic Company Law Scholars, Nordic \& European Company Law Working Paper No. 20-12;

34. Hart, O., Zingales, L.: Companies Should Maximize Shareholder Welfare Not Market Value, ECGI Finance Working Paper No. 521/2017.

-DOI: https://doi.org/10.2139/ssrn.3004794

35. Hill, J.: Then and Now: Professor Berle and the Unpredictable Shareholder, University Law Review, 33 2010, p. 1005, 1009-10.

36. Horak, H., Poljanec, K.: Recent developments in European Company Law: A way forward to a more social Europe?, Intereulaweast, 5(2) 2018, p. 151-163.

-DOI: https://doi.org/10.22598/iele.2018.5.2.5

37. Hsieh, N., Meyer, M., Rodin, D. van 't Klooster J.: The social purpose of corporations, Journal of the British Academy, 6(s1) 2018, p. 49-73.

-DOI: https://doi.org/10.5871/jba/006s1.049

38. Hume, D.: A Treatise of Human Nature, Oxford University Press, [1739] 1978. -DOI: https://doi.org/10.1093/actrade/9780198245872.book.1

39. Inglehart, R., Welzel R.: Modernization, cultural change, and democracy: the human development sequence, Cambridge University Press, Cambridge, 2005, p. 23.

40. Johnston A.: Reforming English Company Law to Promote Sustainable Companies, European Company Law 11(2) 2014, p. 63-66.

41. Judgment of the Regional Court for the City Warsaw, District Śródmieście, dated 24.01.2019, VI C 1043/18.

42. Judgment of the Regional Court for the City Warsaw, District Śródmieście, dated 1.10.2019 r, II C 661/19.

43. Katelouzou, D., Zumbansen, P.:, The New Geographies of Corporate Law Production, Transnational Law Institute, King's College London Research Paper Series No. 13/2020, available: [https://papers.ssrn.com/sol3/papers.cfm?abstract_ $\mathrm{id}=3575009]$, accessed on 2.12.2020.

-DOI: https://doi.org/10.2139/ssrn.3575009

44. Kitayama, S., Conway, L., Pietromonaco, P., Park, H., Plaut, V.: Ethos of independence across regions in the United States: the production-adoption model of cultural change, American Psychologist 65 2010, p. 559-574.

-DOI: https://doi.org/10.1037/a0020277 
45. Kollmuss, A. and Agyeman, J.: Mind the Gap: Why Do People Act Environmentally and What Are the Barriers to Pro-Environmental Behavior?, Environmental Education Research, 8(3) 2002, p. 239-60.

-DOI: https://doi.org/10.1080/13504620220145401

46. Kötz, H: Die Ungültigkeit von Verträgen wegen Gesetz- und Sittenwidrigkeit. Eine rechtsvergleichende Skizze, RabelsZ, 58 1994, p. 209.

47. Kuhn, T.: The Structure of Scientific Revolutions, University of Chicago Press, 1970.

48. Lafarre, A., Van der Elst, C.: Shareholder Sustainabilty Activism in the Netherlands, ECGI Law Working Paper No. 396/2018.

-DOI: https://doi.org/10.2139/ssrn.3156614

49. Leiserowitz, A., Kates, R., Parris, T.: Do Global Attitudes and Behaviors Support Sustainable Development?, Environment, 47(9) 2005, p. 37.

-DOI: https://doi.org/10.3200/ENVT.47.9.22-38

50. Lewis, D.: Convention: A Philosophical Study, Cambridge MA, Harvard University Press, 1969.

51. Liao, C.: Social Enterprise Law: Friend of Foe to Corporate Sustainability, in: Sjåfjell, B., Bruner, C. (eds.): The Cambridge Handbook of Corporate Law, Corporate Governance and Sustainability, Cambridge University Press 2020, p. 669-681.

-DOI: https://doi.org/10.1017/9781108658386.053

52. Licht, A.: Varieties of Shareholderism: Three Views of the Corporate Purpose Cathedral, ECGI Law Working Paper No. 547/2020.

-DOI: https://doi.org/10.2139/ssrn.3718670

53. Malaurie Ph.: L'ordre public et le contract, Etude de droit civil compare (France, Angleterre, URSS), Paris, 1967, p. 132.

54. Manfredo, M. et al.: Why social values cannot be changed for the sake of conservation, Conservation Biology, Volume 31, No 4, 2017, p. 776.

-DOI: https://doi.org/10.1111/cobi.12855

55. Mauerhofer, V.:, Sustainable Development Law in (Only) One World: Challenges and Perspectives for Governance and Governments, in: Mauerhofer, V., Rupo D., Tarquinio L. (eds.): Sustainability and Law. General and Specific Aspects, Springer 2020, p. 15-32.

-DOI: https://doi.org/10.1007/978-3-030-42630-9_2

56. Mayer, C., Shareholderism versus Stakeholderism - A Misconceived Contradiction. A Comment on "The Illusory Promise of Stakeholder Governance" by Lucian Bebchuk and Roberto Tallarita, ECGI Law Working Paper No. 522/2020.

-DOI: https://doi.org/10.2139/ssrn.3617847

57. Mayer, C.: Prosperity: Better business makes the greater good, Oxford University Press, 2018. 
58. Mayer, C.: The Future of the Corporation and the Economics of Purpose, ECGI Finance Working Paper No. 710/2020.

-DOI: https://doi.org/10.2139/ssrn.3731539

59. Mayer, C.: Valuing the invaluable: how much is the planet worth?, Oxford Review of Economic Policy, 35(1) 2019, p. 109-119.

-DOI: https://doi.org/10.1093/oxrep/gry024

60. McAdams, R. H.: The Origin, Development, and Regulation of Norms, Michigan Law Review 96 1997, p. 338.

-DOI: https://doi.org/10.2307/1290070

61. Means, B., Yockey, J. (eds.): The Cambridge Handbook of Social Enterprise Law, Cambridge University Press, 2018.

-DOI: https://doi.org/10.1017/9781316890714

62. Möslein, F.: Reformperspektiven im Recht sozialen Unternehmertums, ZRP 2017, p. 175.

63. Posner E.: Law and Social Norms, Cambridge MA, Harvard University Press, 2000.

64. Qiuhua, L., Wang B., Deng H., Yu C.: A quantitative analysis of global environmental protection values based on the world values survey data from 1994 to 2014, Environmental Monitoring and Assessment 190, 2018, p. 593.

-DOI: https://doi.org/10.1007/s10661-018-6949-Z

65. Radwański Z, Trzaskowski R., in: Radwański Z., Olejniczak A. (eds.): System Prawa Prywatnego, Prawo cywilne - część ogólna, C.H. Beck (Poland), p. 319.

66. Recordings and presentations from a dedicated series of workshops organized by the European Corporate Governance Institute can be found here: [https://ecgi. global/content/directors\%E2\%80\%99-duties-and-sustainable-corporate-governance\#! event-presentations], accessed on 2.12.2020.

67. Report of the European Environment Agency, „The European environment - state and outlook 2020. Knowledge for transition to a sustainable Europe“, [https://www.eea.europa.eu/publications/soer-2020], accessed on 2.12.2020.

68. Research conducted within the program "The future of the corporation" led by Mayer, C. within the British Academy, [https://www.thebritishacademy.ac.uk/ programmes/future-of-the-corporation/research/], accessed on 2.12.2020.

69. Rock, E.: For Whom is the Corporation Managed in 2020? The Debate Over Corporate Purpose, ECGI Law Working Paper No. 515/2020.

-DOI: https://doi.org/10.2139/ssrn.3589951

70. Roe, M., Spamann H., Fried J. M., Wang C. C. Y.: The European Commission's Sustainable Corporate Governance Report: A Critique, ECGI Law Working Paper No. 553/2020;

-DOI: https://doi.org/10.2139/ssrn.3711652 
71. Rühmkorf, A.: Stakeholder Value versus Corporate Sustainability. Company Law and Corporate Governance in Germany, in: Sjåfjell, B., Bruner, C. (eds.): The Cambridge Handbook of Corporate Law, Corporate Governance and Sustainability, Cambridge University Press 2020, p. 236.

-DOI: https://doi.org/10.1017/9781108658386.023

72. Safjan, M.: Klauzule generalne w prawie cywilnym (przyczynek dodyskusji), Państwo i Prawo 11 1900, p. 53.

73. Safjan, M.: Kodeks cywilny, Vol. I, Online Commentary to Art. 56, sec. 31, C.H. Beck, 2020.

74. Schubert, C.: Münchener Kommentar zum BGB, 8. Auflage 2019, p. 94.

75. Schwartz, S.H., Bilsky, W.: Toward a theory of the universal content and structure of values: extensions and cross-cultural replications, Journal of Personality and Social Psychology, 58 1990, p. 878-891.

-DOI: https://doi.org/10.1037/0022-3514.58.5.878

76. Simitis, K., Gute Sitten und Ordre Public, Elwert, 1960.

77. Sjåfjell, B., Bruner, C.: Corporations and Sustainability, in: Sjåfjell, B., Bruner, C. (eds.): The Cambridge Handbook of Corporate Law, Corporate Governance and Sustainability, Cambridge University Press, 2020, p. 6.

-DOI: https://doi.org/10.1017/9781108658386

78. Sjåfjell, B., Mähönen, J.: Upgrading the Nordic Corporate Governance Model for Sustainable Companies, European Company Law, 11(2) 2014, p. 58-62.

79. Sjåfjell, B.: Regulating for Corporate sustainability: Why the public-private divide misses the point, in: Choudhury, B., Petrin, M. (eds.): Understanding the company, Cambridge University Press, 2017, p. 145-165.

-DOI: https://doi.org/10.1017/9781316536384.008

80. Sjåfjell, B.: Sustainable Value Creation Within Planetary Boundaries-Reforming Corporate Purpose and Duties of the Corporate Board, Sustainability 2020, 6245, p. $1-15$.

-DOI: https://doi.org/10.3390/su12156245

81. Sjåfjell, B.: The Courts as Environmental Champions: The Norwegian Hempel Cases, European Company Law, 13(5) 2016, p. 199-206.

82. Sjafjell, B.: Responding to the Grand Challenge of Our Time, in: Eftestøl-Wilhelmsson, E., Sankari, S., Bask A. (eds.): Sustainable and Efficient Transport. Incentives for Promoting a Green Transport Market, Edward Elgar 2019.

83. Sneirson, J.: The history of shareholder primacy, from Adam Smith through the rise of financialism, in: Sjåfjell B., C. Brunes (eds.): The Cambridge Handbook of Corporate Law, Corporate Governance and Sustainability, Cambridge University Press, 2020, p. 73-85.

-DOI: https://doi.org/10.1017/9781108658386.011 
84. Stern, P. C.: Toward a Coherent Theory of Environmentally Significant Behavior, Journal of Social Issues 56(3) 2000, p. 407-424.

-DOI: https://doi.org/10.1111/0022-4537.00175

85. Strine L.: Toward Fair and Sustainable Capitalism. A Comprehensive Proposal to Help American Workers, Restore Fair Gainsharing Between Employees and Shareholders, and Increase American Competitiveness by Reorienting Our Corporate Governance System Toward Sustainable Long-Term Growth and Encouraging Investments in America's Future, University of Pennsylvania Law School, Institute for Law and Economics, Research Paper No. 19-39.

86. Sugden, R.: The Economics of Rights, Cooperation and Welfare, Oxford, Basil Blackwell, 1986.

87. Sunstein, C.: Social Norms and Social Roles, Columbia Law Review, 96 1996, p. 904.

- DOI: https://doi.org/10.2307/1123430

88. Sustainable Development Goals Report 2020, [https://unstats.un.org/sdgs/report/2020/], accessed on 2.12.2020.

89. Thommen, W.: Beitrag zur Lehre vom Begriff der guten Sitten im schweizerischen Privatrecht, Winterthur, 1954.

90. Ullmann-Margalit, E.: The Emergence of Norms, Oxford University Press, 1977.

91. Young, P.: The evolution of conventions, Econometrica, 61 1993, p. 57-84.

-DOI: https://doi.org/10.2307/2951778

92. Zimmermann, R.: The Law of Obligations, Roman Foundations of the Civilian Tradition, Clarendon Press, 1996, p. 697-705.

-DOI: https://doi.org/10.1093/acprof:oso/9780198764267.001.0001

93. Zweigert, K., Kötz, H.: Introduction to Comparative Law, Oxford University Press, p. 380, 381. 